SINET: Ethiop. J. Sci., 22(1):113-126, 1999

(1) Faculty of Science, Addis Ababa University, 1999

ISSN: 0379-2897

\title{
MICROBIOLOGY OF THE FERMENTATION OF SHAMITA, A TRADITIONAL ETHIOPIAN FERMENTED BEVERAGE
}

\author{
Ketema Bacha ${ }^{1}$, Tetemke Mehari ${ }^{2}$ and Mogessie Ashenafi ${ }^{3, *}$ \\ ${ }^{1}$ Department of Biology, Faculty of Science; Addis Ababa University \\ ${ }^{2}$ Department of Chemistry, Faculty of Science; Addis Ababa University \\ ${ }^{3}$ Department of Microbiology and Immunology, Institute of Pathobiology. \\ Addis Ababa University, PO Box 1176, Addis Ababa, Ethiopia
}

\begin{abstract}
Shamita is a low-alcohol traditional beverage made by overnight fermentation of mainly roasted barley flour and consumed as meal-replacement. The microbiology of shamita was studied using several general, selective and differential media. All ingredients and the clay jar rinse water had large numbers ( $>10^{4}$ colony forming units (cfu) per gram or millilitre) of aerobic mesophilic bacteria (AMB) made up mostly of Bacillus spp. and micrococci. Barley malt contributed most of the lactic acid bacteria (LAB) and yeasts which were most important to the fermentation and dominated the fermentation flora reaching final counts of $10^{9}$ and $10^{7} \mathrm{cfu}(\mathrm{ml})^{-1}$, respectively. Heterofermentative and homofermentative Lactobacillus spp. were the major groups of LAB isolated from the fermenting shamita. The $\mathrm{pH}$ dropped from an initial value of 5.80 to 4.03 over the $24 \mathrm{~h}$ period of fermentation. Coliforms and other members of Enterobacteriaceae as well as moulds were eliminated after $16 \mathrm{~h}$ fermentation. Laboratory prepared shamita had comparable microbial counts with samples collected from local shamita brewers in Addis Ababa.
\end{abstract}

Key words/phrases: Shamita, beverage, cereal fermentation

\section{INTRODUCTION}

Fermentation is one of the effective and the most economical methods of processing and preserving foods and beverages acceptable to man. The method

* Author to whom all corredpondence should be addressed. 
is inexpensive, easily acceptable, adaptable and applicable at house-hold level in traditional communities (Pederson, 1979; Nout, 1993; Johansson, 1995). Fermentation processes enhance the nutritional quality of raw ingredients by improving the digestibility of nutrients and inactivating anti-nutritional factors (Van Veen and Steinkraus, 1970; Nout, 1993). They also improve the acceptability of the food by destroying undesirable flavours of the raw ingredients (Steinkraus, 1983).

Practically, every civilization has developed some type of fermented food and beverage. The early men probably used fermented beverages as a substitute for safe water. Such beverages are usually non-intoxicating if consumed during the early stages of fermentation as the alcohol level will still be low (Rose, 1977). The traditionally fermented beverages are low-cost products in all aspects as they are usually manufactured using only rudimentary equipment. Because of their cheapness, they are mostly consumed by low income groups. Thus their handling and consumption often takes place under conditions of poor hygiene (Steinkraus, 1983).

Ethiopia is one of the countries where a variety of traditional fermented foods and beverages are produced and consumed. The beverages are produced on a fairly small scale and usually for local consumption. Among Ethiopian fermented beverages are varieties of Tella, Tej, Katikala (areki), Korefe, Borde, Shamita, Keribo, Imbushbush, etc.

Shamita is a widely consumed beverage in different regions of Ethiopia. It has a thick consistency and is consumed as meal replacement by most people who cannot afford a reasonable meal. It is produced by fermenting roasted barely overnight. Malt is not commonly used in shamita fermentation, although local shamita brewers in Addis Ababa use it frequently, and starch is the only principal fermentable carbohydrate. The microorganisms responsible for fermentation are mostly from back-slopping using a small amount of shamita from a previous fermentation as well as from the ingredients and equipment. Ready-to-consume shamita has high microbial counts $\left[10^{6}-10^{7} \mathrm{cfu}(\mathrm{ml})^{-1}\right]$ made up of mostly lactic acid bacteria and yeast. These microorganisms make the product a good source of microbial protein. However, shamita has poor keeping quality because of these high numbers of live microorganisms and becomes too sour about four hours after being ready for consumption (Mogessie Ashenafi and Tetemke Mehari, 1995). 
Although shamita is one of the most important beverages which are used as meal-replacements in Ethiopia, there is no detailed information on its fermentation with respect to the important microorganisms that carry out the process. The objective of this study was, therefore, to examine the fermentation process in detail in order to determine the dynamics of the important groups of microorganisms that initiate and carry out the fermentation.

\section{MATERIALS AND METHODS}

\section{Preparation of shamita}

The stock ingredients used for the preparation of Shamita were barley (Hordeum vulgare), ground linseed to ensure thick consistency for the product, salt (sodium chloride) mainly to improve taste of the fermented product and spices (Ethiopian Caraway and False Cardamon) to impart characteristic flavour to the product. All the materials used for the fermentation were purchased from a local market in Addis Ababa.

For stock preparation, $125 \mathrm{~kg}$ of barley was soaked in excess water for $15 \mathrm{~min}$. The excess water was then strained off and the soaked barley was dehulled using mortar and pestle. This was allowed to air dry for a short period and the free seed coat was removed. The dehulled barley was then roasted on a flat metal pan until it turned light brown. After a further dry dehulling, the roasted barely was ground finely. The ingredients, $100 \mathrm{~kg}$ of barley flour, $3 \mathrm{~kg}$ of salt, $9 \mathrm{~kg}$ of ground linseed and about 20-25 $\mathrm{g}$ of assorted spices were mixed. This constituted the stock ingredient out of which the required amount was taken for each preparation of shamita.

A clay jar with a capacity of about 90 litres was used for shamita preparation in this study. This was thoroughly cleaned with water and allowed to dry in air after each preparation. Shamita was prepared by an experienced female shamita brewer following traditional procedures.

For each laboratory preparation of shamita, $25 \mathrm{Kg}$ of the stock ingredient was thoroughly mixed with 50 litres of tap water (Fig. 1). Although it has been uncommon to use malt for shamita preparation in southern Ethiopia (Mogessie Ashenafi and Tetemke Mehari, 1995), malt has been frequently used in Addis Ababa. Therefore, $150 \mathrm{~g}$ of barley malt was added to the above mixture. One 
litre of shamita from a previous fermentation was added as a starter and the whole gruel was sealed tightly with mud and allowed to ferment overnight at ambient temperature. As bird's eye chilli (Capsicum minimum) is optionally added depending on the consumer's interest, a small amount was added to the ready-to-consume product.

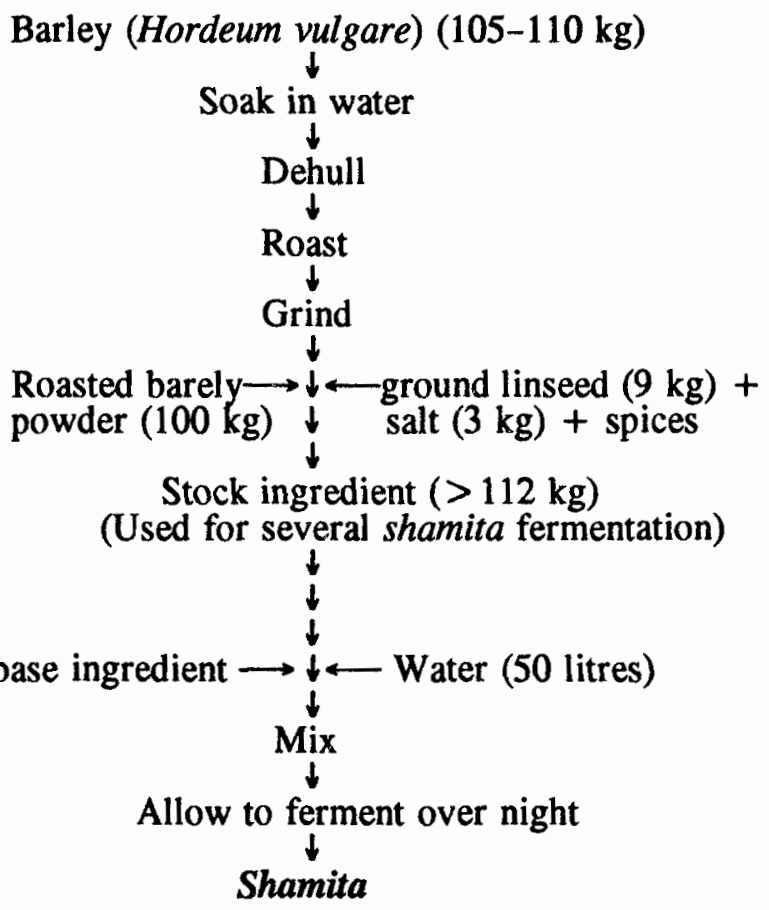

Fig. 1. Flow chart of laboratory shamita fermentation process.

Three different fermentation processes were carried out for this study and results are average values. 


\section{Sampling}

Samples were separately taken from ingredients $(25 \mathrm{~g})$ used for shamita fermentation and from the rinse water $(25 \mathrm{ml})$ of the jar used for brewing. In addition, $25 \mathrm{ml}$ of sample were aseptically removed from the fermenting mash at four-hour intervals for $24 \mathrm{~h}$ for analysis. Moreover, ready-to-consume shamita samples (10) were also collected from local brewers in Addis Ababa.

\section{Microbiological analyses}

Samples, $25 \mathrm{~g}$ of each ingredient, $25 \mathrm{ml}$ each of the samples from fermenting mash drawn at intervals and of ready-to-consume shamita obtained from local brewers were separately blended in $225 \mathrm{ml}$ of sterile physiological saline solution. The samples were homogenized and appropriate dilutions surface plated on the respective media for counting.

Aerobic mesophilic bacteria were counted on Plate Count (PC) agar after incubation at $32^{\circ} \mathrm{C}$ for 24-48 h. Violet Red Bile (VRB) agar was used to count coliforms. After $24 \mathrm{~h}$ incubation at $32^{\circ} \mathrm{C}$, purplish red colonies surrounded by red zone of precipitated bile were counted as coliforms. Enterobacteriaceae were enumerated on Violet Red Bile Glucose (VRBG) agar and incubated at $32^{\circ} \mathrm{C}$ for $24 \mathrm{~h}$. Purple red colonies were counted as belonging to the Enterobacteriaceae. Staphylococci were enumerated on Mannitol Salt agar after incubation at $32^{\circ}$ $\mathrm{C}$ for $36 \mathrm{~h}$. Lactic acid bacteria were counted on de-Mann, Rogosa and Sharpe (MRS) agar plates after incubation in an anaerobic jar (Oxoid) at $32^{\circ} \mathrm{C}$ for 48 h. Yeasts and moulds were counted on Chloramphenicol-Bromophenol Blue (CBB) agar plates (yeast extract, $5.0 \mathrm{~g}$; glucose, $20.0 \mathrm{~g}$; chloramphenicol, 0.1 $\mathrm{g}$; bromophenol blue, $0.01 \mathrm{~g}$; agar, $15 \mathrm{~g}$; distilled water, $1000 \mathrm{ml} ; \mathrm{pH}$, 6.0-6.4). Colonies were counted after incubation at $28-30^{\circ} \mathrm{C}$ for 4 to 5 days. For bacterial spore counting, appropriate dilutions were heat-treated at $80^{\circ} \mathrm{C}$ for $10 \mathrm{~min}$ in a water bath, and plated on PC agar. Colonies were counted after incubation at $32^{\circ} \mathrm{C}$ for $48 \mathrm{~h}$.

\section{Flora assessment}

Ten to fifteen colonies were picked from countable plates of PC, MRS and CBB agar plates. They were purified by repeated plating after colony counting. Cell shape, cell grouping pattern, motility and presence or absence of endospores were determined microscopically on wet mounts. $\mathrm{KOH}$ test was carried out according to Gregersen (1978) to distinguish between Gram-positive and Gram negative bacteria. Presence of cytochrome oxidase was tested by the method of 
Kovacs (1956), and catalase test was performed by flooding young cultures with $10 \% \mathrm{H}_{2} \mathrm{O}_{2}$ solution (MacFaddin, 1980). Oxidation/Fermentation test for Gram negative rods was carried out in Hugh and Leifson O/F medium while BairedParker's modification of Hugh and Leifson medium was used for Gram positive cocci as described by Collins and Lyne (1976).

Gram positive, non-spore forming, catalase-negative cocci, coccobacilli or rods isolated from MRS agar plates were considered as lactic acid bacteria and further grouped into different genera by testing for gas production in $5 \%$ glucose in MRS broth. Incubation was at $32^{\circ} \mathrm{C}$ for 5 days.

Based on the information obtained, the various microbial groups were identified according to Bergey's Manual (Sneath $e t$ al., 1986), and Lodder (1971). Change in $\mathrm{pH}$ in the fermenting mash and that of samples collected from local brewers was measured using a pH meter (Beckmann).

\section{RESULTS AND DISCUSSION}

Although the traditional steps of fermentation were followed in this study, attempts were made to reduce the load of natural microflora associated with ingredients. Barley used for malting was steeped in water repeatedly and that used for roasting was washed and dehulled before further processing. Despite all these efforts, however, considerable numbers of aerobic spores and moulds were still isolated from ingredients. All ingredients and the clay jar were sources of considerable numbers and variety of aerobic mesophilic bacteria [>10 $\mathrm{cfu}(\mathrm{g})^{-1}$ or $\mathrm{ml}$ ] (Table 1). This flora was dominated by Bacillus spp. and micrococci. These bacteria could be sources of amylolytic enzymes useful for the degradation of starch to fermentable sugars which could then be utilized by $\mathrm{LAB}$ and yeasts. Other aerobic mesophilic bacteria were found in lower numbers (Table 1). Basically cereal grains and meals are prone to contamination by mould, yeasts and bacteria (Nout, 1980; Ogundiwin et al., 1991).

Barley malt contained all groups of microorganisms considered in this study at a markedly high level (Table 1). Microbial load of ground barley in our study [about $10^{4} \mathrm{cfu}(\mathrm{g})^{-1}$ ] was similar to those observed in flour sampled at mills in which counts were generally in the range of $10^{2}$ to $10^{3} \mathrm{cfu}(\mathrm{g})^{-1}$ (Banwart, 1979). In addition to the role played by malt enzymes in degrading starch, the presence 
of high numbers of LAB and yeasts makes malt an important component of the fermentation process. Most of the isolates belonging to the Enterobacteriaceae were not capable of fermenting sucrose and thus may not contribute markedly in the initiation of the fermentation. Among the Enterobacteriaceae, coliforms were present in malt at counts of about $10^{4} \mathrm{cfu}(\mathrm{g})^{-1}$. Although coliforms are generally relevant from the safety point of view, they may also be important in the initiation of fermentation when maltose or glucose become available in the fermenting mash through the action of enzymes from malt or other amylolytic microorganisms.

The spices contributed a substantial number of aerobic mesophilic bacteria, mainly Bacillus spp. and micrococci, as well as yeasts and moulds. Counts as high as $10^{7} \mathrm{cfu}(\mathrm{g})^{-1}$ were reported for various types of spices in different studies (Tjaberg et al., 1972; Lindberg, 1997). In shamita fermentation, spices are used to impart good flavour to the final product. However, they also contribute a high number of different microorganisms which may affect the quality of the final product.

The high count of microorganisms found in the rinse from the clay jar used for fermentation indicated that the jar was also a good source of microorganisms, particularly yeasts and micrococci.

The lactic acid bacteria (LAB) were found to be the most important microbial groups in determining the nature of fermentation and its product. LAB started at counts $<10^{6} \mathrm{cfu}(\mathrm{ml})^{-1}$ at $0 \mathrm{~h}$ and reached counts as high as $10^{8} \mathrm{cfu}(\mathrm{ml})^{-1}$ within 8 hours and over $10^{9} \mathrm{cfu}(\mathrm{ml})^{-1}$ at $24 \mathrm{~h}$ (Fig. 2). This increase was accompanied by a fall in pH (Table 2). Marked variation in LAB count was noted only at $0 \mathrm{~h}$ in the three sets of fermentation processes. Streptococcus and Pediococcus were below detectable levels $\left[<10^{2} \mathrm{cfu}(\mathrm{ml})^{-1}\right]$ during shamita fermentation. Lactobacillus spp. were the major groups of LAB in this study, with the heterofermentative lactobacilli dominating up to $16 \mathrm{~h}$ of fermentation and the homofermentative ones becoming more prominent at $24 \mathrm{~h}$ (Table 2). The simultaneous fermentative importance of both heterofermentative and homofermentative lactobacilli was also reported in the fermentation of Kenyan 'bussa' (Nout, 1980). These groups of microorganisms were also important in the fermentation of various traditional fermented beverages such as Mexican 'pulque' (Sanchez-Marroquin and Hope, 1953), Ghanian wine (Nyako, 1977) and Nigerian 'burukutu' and 'obiolor' (Achi, 1990; Owuama, 1991). 

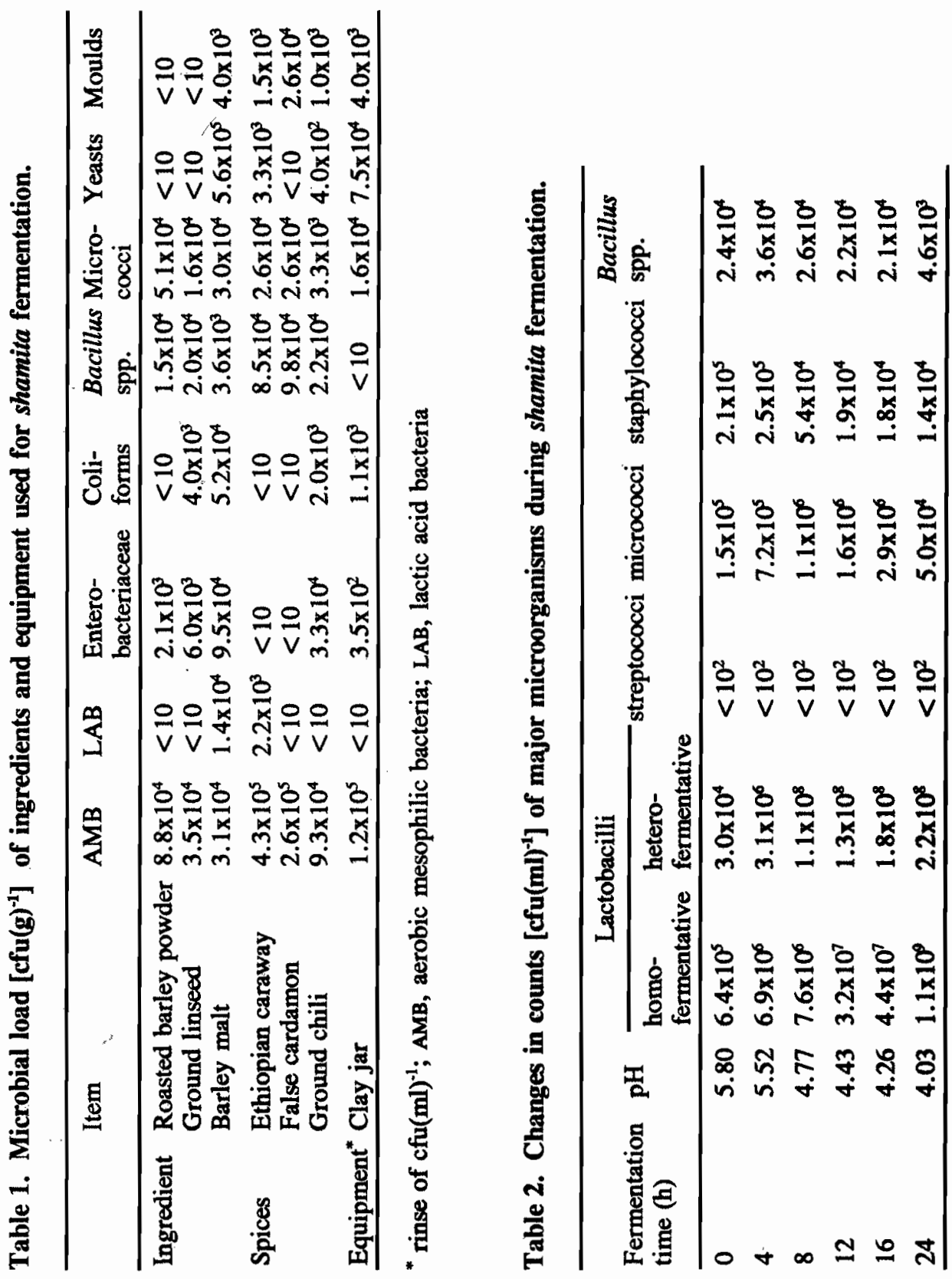


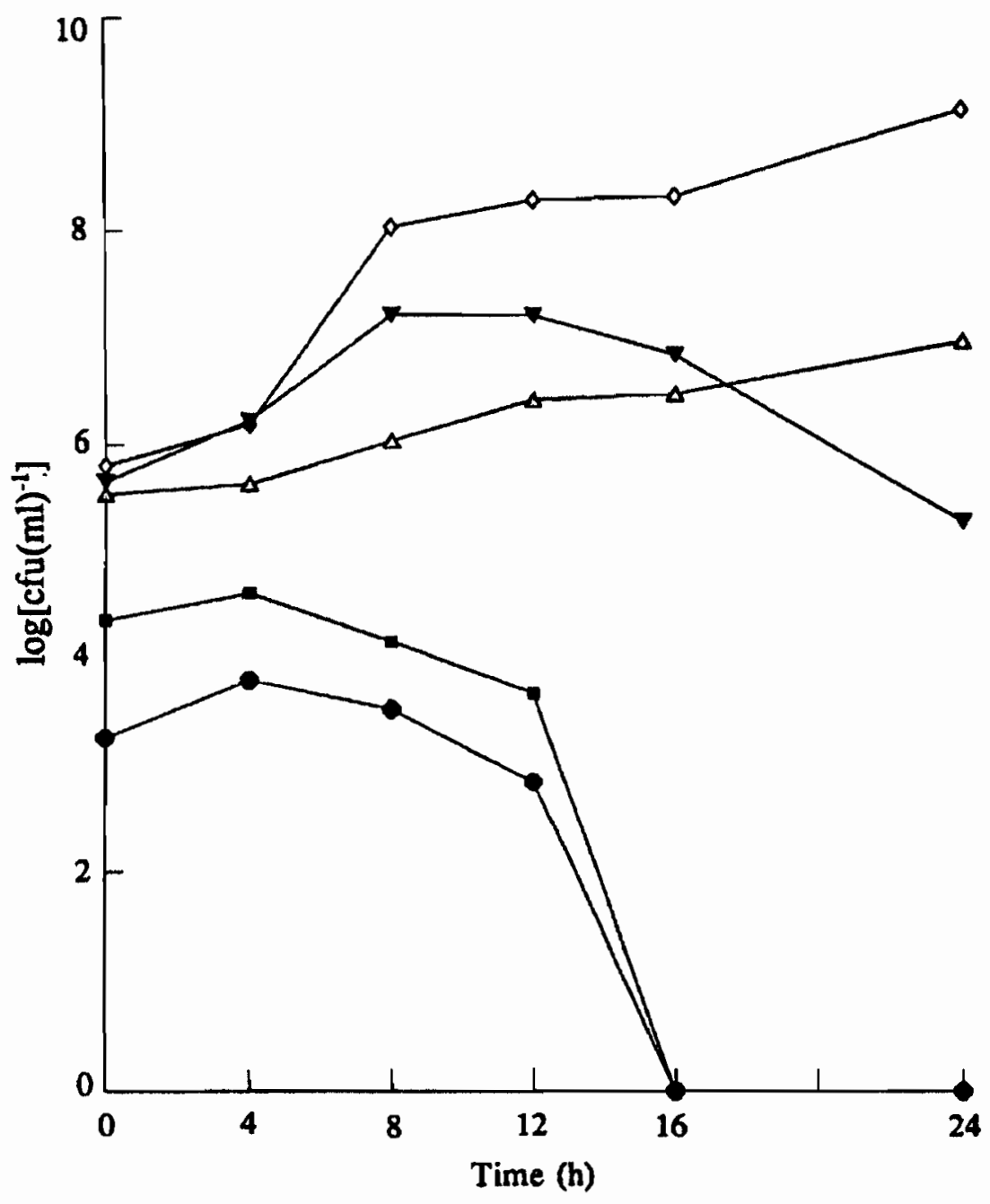

$\neg-$, AMB; $\diamond$, LAB; - , Yeasts; $\rightarrow$, EB; $\rightarrow$, Coli.

Fig. 2. Increase in counts of aerobic mesophilic bacteria (AMB), lactic acid bacteria (LAB) and yeasts and elimination of members of Enterobacteriaceae (EB) and coliforms (Coli) during 'shamita' fermentation. 
The initial aerobic mesophilic bacterial count at the start of fermentation was around $10^{5} \mathrm{cfu}(\mathrm{ml})^{-1}$ and increased by over $1 \log$ unit until $8 \mathrm{~h}$ (Fig. 2). It, however, fell down to $10^{5} \mathrm{cfu}(\mathrm{ml})^{-1}$ at the end of fermentation. Counts of aerobic mesophilic bacteria varied significantly (Coefficient of variation, $\mathrm{CV}=13-15 \%)$ until $12 \mathrm{~h}$ in the three sets of fermentation processes conducted in this study (individual results not shown). Variations in initial stages may be due to variations in microbial load of ingredients and the uncontrolled spontaneous nature of the fermentation. No significant variation was noted after $12 \mathrm{~h}(\mathrm{CV}<10 \%)$. The aerobic mesophilic bacterial flora was dominated mainly by staphylococci, micrococci and Bacillus spp. (Table 2 ). These groups of bacteria are relatively more heat resistant than Gram negative rods and can thus survive the roasting step and have a high number at the initiation of fermentation. Micrococcus spp. may acidify the flour and water paste while Bacillus spp. may metabolize sugars heterofermentatively producing lactic acid, gas, alcohol, acetoin and small amounts of esters and aromatic compounds (ICMSF, 1980).

The coliform counts and counts of Enterobacteriaceae were relatively lower at the start of the fermentation, mainly due to the heat treatment of fermenting materials in the pre-fermentation process. These groups of microorganisms slightly increased in number until $4 \mathrm{~h}$ and were undetectable at $16 \mathrm{~h}$ of fermentation and thereafter (Fig. 2) possibly due to the unfavourable conditions created by dropping $\mathrm{pH}$. Thus fermentation enhances the microbiological safety of shamita by eliminating possible pathogens that belong to the Enterobacteriaceae as observed in other studies (Gulilat Dessie et al., 1996).

There were relatively high numbers of yeasts at the initiation of fermentation $\left[5.5 \times 10^{5} \mathrm{cfu}(\mathrm{ml})^{-1}\right]$ and increased gradually and reached final counts of about $10^{7} \mathrm{cfu}(\mathrm{ml})^{-1}$ at the completion of fermentation. Counts at different stages of fermentation in the three sets of fermentation processes varied significantly (CV > 10\%) although the increasing trend was maintained in all cases. The flora was dominated by Saccharomyces spp. although Rhodotorula spp. were also isolated at the different stages of fermentation. These two genera have also been encountered in the fermentation of 'tella', a traditional Ethiopian alcoholic beverage (Samuel Sahle and Berhanu Abegaz Gashe, 1991). Since the major ingredient is roasted barely, the fermentable sugars only become available to 
Saccharomyces spp. towards the end of fermentation after the higher sugars have been acted upon by the amylolytic enzymes from malt and the other microbes. Rhodotorula spp. are inactive and may not contribute to the fermentation.

Shamita is usually consumed within a few hours after the completion of an overnight fermentation while still in an active stage of fermentation. Longer keeping at ambient temperature results in a product which is too sour due to further action of Lactobacillus spp., thus rendering the product unfit for consumption.

Laboratory prepared shamita had comparable microbial counts with samples collected from local brewers in Addis Ababa (Table 3). All collected samples showed no significant variation in final $\mathrm{pH}$ values and yeast counts (C.V. < $10 \%)$. Some variation was detected in counts of aerobic mesophilic bacteria and LAB (C.V. $<13 \%$ ), while variations in counts of micrococci and staphylococci were high (C.V. > 15\%). The variations could arise from the varying microbial load of the ingredients. The counts of staphylococci in most cases was $<10^{5} \mathrm{cfu}(\mathrm{ml})^{-1}$, and at this level and $\mathrm{pH}$ values, enterotoxigenic strains would probably not produce sufficient toxin to cause any syndrome (Tatini et al., 1973). It is worth noting that those samples with $\mathrm{pH}$ values higher than 4.3 contained members of Enterobacteriaceae [ $\left.>10^{3} \mathrm{cfu}(\mathrm{ml})^{-1}\right]$. It may thus be important to allow the fermentation to proceed for a longer time $(>16 \mathrm{~h})$ to attain a low enough pH to eliminate members of Enterobacteriaceae.

This study produced basic data on the microbial dynamics which occur during the fermentation of shamita. As shamita is usually consumed by low-income groups as a meal-replacement in different parts of Ethiopia, there may be a need to consider production to a large scale. It is important to note, however, that the scaling-up of indigenous fermentation processes should be undertaken with great care in order not to lose the nutritive value as well as the public acceptance of the beverages. 
Table 3. Counts ( $\log \mathrm{cfu} / \mathrm{ml})$ of various groups of microorganisms from shamita samples collected from local brewers.

\begin{tabular}{|c|c|c|c|c|c|c|c|c|}
\hline Sample & $\mathrm{pH}$ & $\mathrm{AMB}^{\mathrm{I}}$ & $\mathrm{LAB}^{2}$ & $\begin{array}{l}\text { Enterobac- } \\
\text { teriaceae }\end{array}$ & Yeasts & Moulds & Micrococci & $\begin{array}{l}\text { Staphy- } \\
\text { lococci }\end{array}$ \\
\hline 1 & 4.43 & 7.41 & 7.15 & 4.08 & 6.91 & 3.45 & 6.15 & 5.0 \\
\hline 2 & 4.38 & 6.62 & 7.70 & 3.71 & 6.43 & $<1$ & 4.40 & 4.32 \\
\hline 3 & 3.98 & 8.68 & 6.36 & $<1$ & 7.58 & $<1$ & 4.36 & 3.41 \\
\hline 4 & 4.15 & 9.63 & 6.54 & $<1$ & 7.56 & 3.0 & 5.65 & 4.36 \\
\hline 5 & 4.41 & 7.59 & 5.71 & 3.79 & 6.26 & 4.0 & 6.54 & 5.23 \\
\hline 6 & 3.99 & 8.62 & 7.83 & $<1$ & 7.61 & $<1$ & 5.60 & 4.25 \\
\hline 7 & 4.36 & 7.40 & 5.83 & 4.18 & 6.46 & 3.32 & 5.30 & 4.0 \\
\hline 8 & 4.06 & 6.58 & 6.76 & $<1$ & 7.51 & $<1$ & 3.70 & 3.26 \\
\hline 9 & 4.22 & 8.00 & 5.75 & $<1$ & 6.67 & 2.15 & 4.95 & 4.70 \\
\hline 10 & 4.18 & 7.36 & 6.51 & $<1$ & 7.46 & 3.11 & 4.48 & 5.0 \\
\hline $\bar{x}$ & 4.22 & 7.79 & 6.61 & & 7.05 & & 5.11 & 4.35 \\
\hline S.D. & 0.17 & 0.96 & 0.76 & & 0.55 & & 0.89 & 0.66 \\
\hline$\% \mathrm{C.V}$ & 4.1 & 12.3 & 11.5 & & 7.85 & & 17.45 & 15.2 \\
\hline Lab brewed (12 h) & 4.26 & 7.47 & 8.34 & $<1$ & 7.00 & $<1$ & 6.46 & 4.26 \\
\hline
\end{tabular}

AMB, Aerobic Mesophilic Bacteria; LAB, Lactic Acid Bacteria.

\section{ACKNOWLEDGMENT}

The financial assistance to KB by SAREC is acknowledged.

\section{REFERENCES}

1. Achi, O.K. (1990). Microbiology of 'Obiolor', a Nigerian fermented non-alcoholic beverage. J. Appl. Bacteriol. 69:321-325.

2. Banwart, G.J. (1979). Basic Food Microbiology. AVI Publishing Company, Inc. Westport, Connecticut.

3. Collins, C.H. and Lyne, P.M. (1976). Microbilogical Methods. 4th ed. Butterworth and Co. Ltd. Publisers, London. 
4. Gregersen, T. (1978). Rapid method for distinction of Gram negative from Gram positive bacteria. Europ. J. Appl. Microbiol. 5:123-127.

5. Gulilat Dessie, Kebede Abegaz and Mogessie Ashenafi (1996). Fate of Salmonella enteritidis and Salmonella typhimurium during the fermentation of "siljo", a traditional Ethiopian fermented product. East Afr. Med. J. 73:432-434.

6. ICMSF (1980). Microbial Ecology of Foods. Vol. II, Food Commodities. International Commission on Microbiological Spécifications for Foods, Academic Press, New York.

7. Johansson, M.L. (1995). Systematics and starter culture selection of Lactobacillus for human intestine and Nigerian 'ogi', with special reference to Lactobacillus plantarum. PhD Dissertation, Lund University, Sweden.

8. Kovacs, S.N. (1956). Identification of Pseudomonas pyocyaneae by the oxidase reaction. Nature 178:173.

9. Lindberg, A.M. (1997). Characterization of Aeromonas, Enterobacteriaceae, Pseudomonas, Bacillus and Lactobacillus spontaneously growing to high numbers in milk, minced meat, fish or cheese. PhD Dissertation, Lund University, Sweden.

10. Lodder, J. (1971). The Yeasts. A taxonomic study. North Holland Pub. Comp. Amsterdam.

11. MacFaddin, J.F. (1980). Biochemical Tests for Identification of Medical Bacteria, 2nd ed. Williams and Wilkins, Baltimore.

12. Mogessie Ashenafi and Tetemke Mehari (1995). Some microbiological and nutritional properties of 'Borde' and 'Shamita', traditional Ethiopian fermented beverages. Ethiop. J. Health Dev. 9:105-110.

13. Nout, M.J.R. (1993). Processed weaning foods for tropical climates. Int. J. Food Microbiol. 4:213-221.

14. Nout, M.J.R. (1980). Microbiological aspects of the traditional manufacture of Bussa, a Kenyan opaque maize beer. Chem. Mikrobiol. Technol. Lebensm. 6:137-142.

15. Nyako, K.O. (1977). Palm wine, an alcoholic beverage of Ghana. In: Symposium on Indigenous Fermented Foods, pp. 315-328, (Steinkraus, K.H., ed.) Marcel Dekker, Inc. New York.

16. Ogundiwin, J.W., Iloric, M.O., Fessehatzion, B., Babololar, G.O. and Olajuyigbe, A. (1991). Effect of chemical treatment on the microorganisms associated with malting of sorghum grains and sorghum malt. J. Appl. Bacteriol. 7:139-143. 
17. Owuama, C.I. (1991). Production of 'burukutu' with Saccharomyces cerevisae variants. J. Appl. Microbiol. Biotechnol. 35:21-22.

18. Pederson, C.S. (1979). Microbiology of Food Fermentations. 2nd ed. AVI Pub. Com. Westport, pp. 153-203.

19. Rose, A.H. (1977). Alcholic beverages. Econ. Microbiol. 1:413-418.

20. Samuel Sahle and Berhanu Abegaz Gashe (1991). The microbiology of 'Tella' fermentation. SINET: Ethiop. J. Sci. 14:81-92.

21. Sanchez-Marroquin, A. and Hope, P.H. (1953). Agave juice fermentation and chemical composition studies of some species. Agric. Food Chem. 1:246-249.

22. Sneath, P.H.A., Mair, N.S., Sharpe, M.E., and Holt, J.G. (eds). (1986). Bergey's Manual of Systematic Bacteriology. Williams and Wilkins, Baltimore, USA.

23. Steinkraus, K.H. (1983). Handbook of Indigenous Fermented Foods. Marcel Dekker, Inc. New York.

24. Tatini, S.R., Wesela, W.D., Jezeski, J.J. and Morris, H.A. (1973). Production of staphylococcal enterotoxin A in blue, break, Mozzarella and Swiss cheeses. J. Dairy Sci. 56:429-435.

25. Tjaberg, T.G., Underdal, B. and Lunde, G. (1972). The effect of ionizing radiation on the microbiological content and volatile constituent of spices. J. Appl. Bacteriol. 35:473-478.

26. Van Veen, A.G. and Steinkraus, K.H. (1970). Nutritive value and wholesomeness of fermented foods. J. Agric. Food Chem. 6:105-113. 